\title{
"No-one told me it would all be in Catalan!" - Narratives and language ideologies in the Latin American community at school
}

Adriana Patiño-Santos*

\begin{abstract}
This paper discusses the circulation of language ideologies through conversational narrative repertoires among Latin American parents in the secondary education system in Catalonia. Data, gathered in a linguistic ethnography carried out in three secondary schools in the metropolitan area of Barcelona between 2011 and 2013 (RecerCaixa 2010), include fieldwork in the classroom and other spaces of the school in different periods of the school year, as well as narrative repertoires gathered from in-depth interviews with some of the actors (students and parents of Latin American backgrounds). We focus on conversational narrative because it has proved to be an effective methodological resource for gathering evaluative and moral stances amongst tellers (Ochs and Capps 2001). Narrative data are triangulated with observational and interactional information. Some of the findings reveal, amongst other phenomena, the coexistence of a constellation of conflicting language ideologies regarding Catalan as the language of the school.
\end{abstract}

Keywords: conversational narrative, language ideology, parents of Latin American backgrounds

\section{Introduction}

This paper seeks to contribute to the study of conversational narrative $(\mathrm{CN})$ within linguistic ethnography by understanding $\mathrm{CN}$ as a powerful methodological resource, in at least two ways. Firstly, in granting the researcher insight into not just the participants' biography but also the language ideologies asserted through the events and characters depicted in the narratives, and the narrative resources used. Secondly, in offering the researcher important insight into the conditions of production and some of the consequences of the circulation of narratives that have significance for the social actors who participate in the sites that we choose to investigate.

The data for this paper were gathered in a school near the city centre, as part of a multi-sited linguistic ethnography carried out in three secondary schools in the metropolitan area of Barcelona between 2011 and 2013 (RecerCaixa 2010) ${ }^{1}$. The complete data include

\footnotetext{
${ }^{1}$ Research project: "Case studies of the influence of the family, the process of reception and age of arrival in the construction of language attitudes and ideologies in young Latin Americans and Chinese in Catalonia":
}

*Adriana Patiño-Santos. University of Southampton, UK. Email: A.Patino@ soton.ac.uk 
observations made in the classroom and other spaces of the school during different periods of the school year, as well as the storytelling gathered in sociolinguistic interviews with some of students and parents of Latin American backgrounds, which will be the focus of this paper. Due to the difficulties involved in gaining access to the home lives of the Latin American families who form part of this educational community, we organised interviews with both students and parents on the school premises. From these, I focus on parents' use of conversational storytelling in different forms (small stories, anecdotes, etc.), which allow me to observe how they positioned themselves narratively (e.g. De Fina 2003, De Fina, Bamberg, Schiffrin 2006, Bamberg and Georgakopoulou 2008, Georgakopoulou 2006, 2007, 2014), and the language ideologies that these communicative resources conveyed.

As part of the ethnographic data gathered, the conversational narratives emerging from parents' discourses will be triangulated with the voices of other participants, including the researchers' field notes. In what follows, I present the research context and literature review (section 2), the motivations for this study, our ethnographic data and the hybrid theoretical framework within which we will propose conversational narrative as an effective analytical lens through which to investigate how social actors express, justify and propagate, amongst other things, language ideologies (section 3). We will consider the case of Nora ${ }^{2}$ as our focus for the data analysis (section 4) and draw some conclusions (section 5).

\section{Language ideologies amongst Latin Americans in the Catalan education system}

Recercaixa 2010ACUP 00344, funded by Obra Social la Caixa. Although the whole study was conducted in three secondary schools of the metropolitan area of Barcelona, the data for this paper will focus on the ethnography carried out in the Marc Aureli school, near the centre of the city. The whole team were members of the GREILI group, at the Pompeu Fabra University: Mireia Trenchs, Michael Newman, Adriana Patiño-Santos, Larissa Tristán, Laura Canós, Manel Ollé, Chun-chun Chin-Ko and Montserrat Abella. A detailed description of the secondary schools can be found in Trenchs-Parera and Patino-Santos 2013.

${ }^{2}$ All the names of the participants are pseudonyms in order to protect their identities. 
The following interaction between myself, a researcher of Colombian origin, and three Latin American students, illustrates one of the main issues arising amongst Latin Americans enrolled in the Catalan education system:

\section{Example 1}

Participants: Adriana, researcher of Colombian origin, David (17) of Colombian origin, Jordi (15) and Rocco (16) of Ecuadorian origin.

73. ADR: a l'hora d'estudiar / què vol dir que són més estrictes / què vol dir estricte / què vol dir això $\uparrow$ (a David)

74. DAV: (...) és el mateix perquè a veure la diferències que jo he trobat són moltes / són moltes diferències e:h a partir primer que tot de la disciplina / de com ens comportem nosaltres els alumnes llatinoamericans / els alumnes d'aquí / també: la llengua / bueno jo no savia

75. ADR: tu tampoc (a Rocco)

76. ROC: jo: jo tampoc

77. ADR: Jordi tampo- savia / va ser una sorpresa per tothom (a Jordi)

78. TOTS: sil

79. DAV: jo no sabia pas gaire que aquí és feia tot en català / a veure jo tenia com en la ment de que aquí a Espanya no més es parlava espanyol

73. ADR: when it comes to studying / how is it that they are more strict/ what is it to be strict / what does that mean $\uparrow$ (to David)

74.DAV: (...) it's the same because I mean I've found many the differences / there are lots

of differences y'know starting first of all with discipline / like how we behave us Latin American pupils / the pupils from here / also: the language / I mean I didn't know

75. ADR: you neither (to Rocco)

76. ROC: Me: me neither

77. ADR: Jordi didn't know eithe- / it was a surprise for everyone (to Jordi)

78. ALL: yeahl

$\rightarrow$ 79.DAV I didn't have a clue that here everything was done in Catalan / I mean I had it in my head like that here in Spain they only spoke Spanish

In T. 74, David reformulates a previous answer about the comparison between the education system of his country of origin and that of Catalonia. He makes relevant two 
aspects: "discipline" and "language". The language issue is also reinforced by Rocco and Jordi in their own turns. As several studies on the language attitudes, linguistic ideologies and language socialisation processes of Latin Americans in the Catalan context have shown, David's clarification in turn 79 - "I mean I had it in my head like that here in Spain they only spoke Spanish" - confirms that Latin Americans often expect to be taught in Spanish since, prior to their arrival, they did not realise that the vehicular language of education in Catalonia is Catalan (e.g. Corona and Unamuno 2008, Corona, Nusbbaum and Unamuno 2013, Codó and Patiño-Santos 2014, Huguet and Janés 2008, Newman, Patiño-Santos and Trenchs-Parera 2013, Trenchs-Parera and Newman 2009, Trenchs-Parera and Patiño-Santos 2013, amongst many others).

Researchers have also pointed out some of the consequences of this lack of awareness: Latin American parents and children tend to join the Catalan education system assuming that language will not be a problem since they all speak Spanish (albeit different varieties according to their countries of origin [Ecuador, Colombia, the Dominican Republic, etc.] and regions [e.g. Ecuadorian Spanish from Quito and Ecuadorian Spanish from Guayaquil]). On arrival at primary school, they learn the language quickly and display no resistance to being socialised in Catalan (Trenchs-Parera and Patiño-Santos, 2013; Unamuno and Nussbaum, 2006; Oller and Vila, 2010). However, once young Latin Americans move up to secondary school, they often refuse to speak the language of the school, even in the cases in which they have learnt it in primary school. Many reasons have been brought to light from diverse sociolinguistic perspectives, but they all coincide in suggesting that a central role is played by the attitudes and ideologies reported in quantitative research (e.g. Huguet and Janés 2008; Trenchs-Parera and Newman 2009) and documented in qualitative studies (e.g. Corona and Unamuno 2008, Codó and Patiño-Santos 2014; Newman, Patiño-Santos and TrenchsParera 2013, etc.). 
More specifically, in terms of ideologies and attitudes, these Spanish speakers from Latin America make value judgements regarding Spanish / Catalan with a range of characterisations that reflect the distribution of the two languages in daily practice:

- Useful vs. non-useful: the students claim that they do not feel Catalan to be a useful language, especially those orientated towards moving away in the future, either by returning to their countries of origin or choosing to live in other places. In this regard, the U.S. emerges as a preferred destination (see: Newman, Patiño-Santos and Trenchs-Parera 2013, Trenchs-Parera and Patiño-Santos 2013).

- International vs. non-international: Catalan is frequently contrasted with Spanish and English, which are seen as languages of the global market. (Codó and Patiño-Santos 2014).

- Natural vs artificial: Catalan is seen as a language that is not "natural". Latin American Spanish speakers do not find the necessary registers to express themselves (Corona and Unamuno 2008, Newman, Patiño-Santos and Trenchs-Parera 2013)

- Our language vs. their language (Corona et al., 2013, Newman 2011) Group identity amongst some groups of young Latin Americans, self-identified as "Latinos", is based on the combination of features of different varieties of Latin American Spanish, as used in popular culture such as hip-hop, reggaeton, etc. In this regard, some authors even claim that there is an emergent variety, which differentiates members - who can include Catalans and exclude many Latin Americans - from those who are not "Latinos" (Corona, 2010).

- Language of the home vs. language of the school (Gibson and Carrasco 2009, Codó and Patiño-Santos, 2014). Catalan is seen as the language of the school by the students and since the language used at home and in their local neighbourhood is Spanish, in most 
cases school (and in some cases the reception class) is the only place that young Latin Americans are in contact with Catalan language speakers. (Huget 2006a, Trenchs-Parera and Patiño-Santos, 2013)

From the aforementioned characterisations, we can appreciate why school has often been the chosen site to observe language ideologies and practices amongst Latin Americans in Catalonia. It is because most studies have focussed on students' ideologies and practices that we felt that we needed to register the voices of the family, who represent a key locus for the ratification of such ideologies.

\section{$3 \quad$ Research context: Marc Aureli School}

The Marc Aureli secondary school hosts children primarily of working class backgrounds with a significant presence of students of immigrant origins, mainly from Latin America (especially Ecuador, Colombia and the Dominican Republic), and Southern Asia (India and Pakistan) ${ }^{3}$. The original research project from which our case study is taken looked at students and families of Latin American and Chinese backgrounds in the Catalan education system. Our original aim was to compare the language ideologies of the families of these two groups that are perceived differently within Catalan society: Latin Americans are normally perceived as culturally closer, based on historical, cultural and linguistic ties, whilst the Chinese are seen as culturally distant newcomers with language and customs quite remote from those of the Catalans or Spanish. We conducted observations in the classroom and other spaces of the school during different periods of the school year, and interviewed the main social actors within the education system: teachers, students of migrant backgrounds and parents. Results from our ethnographic study on language ideologies among teachers and

\footnotetext{
${ }^{3}$ A complete description of this secondary school can be found in Trenchs-Parera and Patiño-Santos, 2013: 5557)
} 
students of the reception classes have been published previously in several pieces of work (e.g. Trenchs-Parera and Patiño-Santos 2013).

Although our aim as a team was to gather parents' and children's voices in family interactions at home, we had to deal with the reluctance of the participants to be interviewed in a group situation. Some of the children did not want to participate in interviews with the whole family, and some of the parents preferred to be interviewed at school. The school was supportive, but since these parents worked most of the day (some of them working two shifts), they could not always attend our meetings. For that reason, in some cases we visited their workplaces. In the end, we had to settle for interviewing the parents individually. What these reactions showed us was that the parents understood our research as a school-based, institutionalised activity, and this was something that would imply consequences for the data collection, as I will show in the analysis.

We managed to interview ten parents of Latin American origin. These interviews became central for us to start our exploration of the socialisation processes of families of Latin American backgrounds (see Trenchs-Parera and Tristán 2015). For the purposes of this paper, I want to focus on the storytelling produced within the interview with Nora, a mother of Colombian origin, her voice resembles eight of the ten people who participated in this fieldwork. Nora was the parent who displayed the most empathy with the researcher and her in-depth interview turned out to be the richest, not only because it combined the chief language ideologies and stances reported in the other parents' discourses (discourse that were echoed in the students' discursive practices at school - see section 2), but also because once the ice was broken, she talked overtly about her experiences as a migrant in Catalonia. I also draw upon data from the other interviews, as well as my personal experience and observations as a Latin American researcher who has conducted research in peripheral state schools in Barcelona for nearly ten years, for supplementary data that accords with Nora's 
views, and to reveal the common ground found among the Latin American parents interviewed.

\section{Conversational storytelling, language ideologies and linguistic ethnography}

Ochs and Capps' (2001) opened a research inquiry by focussing attention on narratives, as communicative activities, produced by interactants during the course of their daily life conversations. As these authors point out, far from being accomplished storytellers, in our daily lives, we become narrators who are often

bewildered, surprised, or distressed by some unexpected events and begin recounting so that [we] may draw conversational partners into discerning the significance of [our] experiences. Or, narrators may start out with a seamless rendition of events only to have conversational partners poke holes in their story. In both circumstances, narratives are shaped and reshaped turn by turn in the course of conversation. (Ochs and Capps 2001:2).

The main characteristics of conversational storytelling can be summarised as follows: stories are co-constructed, which entails a sharing of the role of the narrator between the initial teller and his/her audience, who can potentially become narrators of the same story. Stories are contingent, which means that they do not follow the canonical organisation (abstract, orientation, complicating action, resolution evaluation, coda) of a structured rounded narrative, but tend to be temporally and causally nonlinear and oscillate back and forth between perspectives; they are polyphonic, since tellers evoke diverse voices of the characters constructed in the narrated world, including themselves. Such polyphony entails the enactment of multiple stances that may be in tension within the various events portrayed 
during the narrative; $\mathrm{CN}$ also allow the tellers to express moral stances in order to justify their actions and choices, which can vary (and even being contradictory) over the course of the narrative. Finally, CNs integrate various forms of discourse (description, chronology, dialogue, etc.) and discursive genres (questions, clarifications, reformulations, etc.); they are social activities, which make them apposite discursive sites to reflect upon individual and group memories, specific situations and individual and collective selves. That is, "for working through who we are and how we should be acting, thinking, and feeling as we live our lives" (Ochs and Capps 2001: 17).

All these characteristics have established the analysis of interactional storytelling, in all its forms, as a consolidated field that has proven fruitful in the study of identity construction and other issues related to the displayed self in daily life (De Fina 2003, De Fina, Schiffrin, and Bamberg 2006; Bamberg, De Fina and Schiffrin 2007; De Fina and Georgakopoulou 2008, 2012, Wortham 2001). More specifically, a focus on the evaluative dimension of narratives has drawn attention to the ways in which tellers make their points (Labov 1972) by employing different communicative resources. Hence, language ideologies as "shared beliefs of common sense notions about the nature of language in the world" (Rumsey 1990:346) have been addressed in narrative inquiry by showing how people represent, perceive and assess their own and others' ways of speaking within recalled experiences. In that sense, narratives produced in multilingual contexts, as a result of migratory processes, have become suitable sites in which to study the role of language ideologies in the construction and positioning of social groups.

As noted by Lanza and Svenden (2007) "What we think about language will be related to how we perceive ourselves and eventually how others perceive us. On a collective level, language is found to be a more crucial core value to some cultural/ ethnic groups than to others" (2007: 291). Thus for example, the testimonies of migrant Latino women in the 
USA have been the focus of research for those scholars who have investigated how these Spanish speaking migrants navigate and struggle within a new linguistic market in which the dominant ideologies of multilingualism and nationalism give rise to classifications of types of "persona" (e.g. native vs. non-native speaker). Such ideologies entail consequences the newcomers who are being classified accordingly. The work of King and De Fina (2010) on Latino women in Washington and that of Relaño-Pastor (2014) on Mexican women in San Diego study narratives on language experiences of groups of Latino women in different settings. Their similar results show, amongst other things, the language ideologies that circulate in connection with the uses of Spanish and English in different areas of the USA. English is portrayed as a social obstacle by the migrants interviewed, and Spanish is racialized and problematized in their storytelling, which covers everyday experiences, in a range of situations, from the workplace to the street. They all show how narratives become spaces for assuming or contesting new or imposed language ideologies. Such studies have inspired work on language ideologies and narratives in different contexts (e.g. Lanza and Sveden 2012, amongst many others).

Similarly, second language teaching and learning environments have been sites for the investigation of how language ideologies produced in narrative inform second language teachers' beliefs and practice. An important and rich reflection of narratives as ideological practices is found in Razfar's (2012) ethnographical work at a secondary school in Southern California, with a dominant presence of students of Latino backgrounds. The author analyses the narratives produced in classroom interaction and in interviews with an ESOL teacher. Broadly speaking, the dominant language ideologies that emerge in the narratives gathered in this work were those of subtractive assimilation. Such ideologies mediate teachers' practices, aimed at encouraging students to achieve proficiency only in English, the second, but socially dominant language. The language of the majority of the students (Spanish) was not valued or 
was perceived to be of lower status. This work is closely related to my own previous research on Latin American students in three reception classes in the metropolitan area of Barcelona (Trenchs-Parera and Patiño-Santos, 2013). Similar assimilationist language ideologies emerged in the narratives gathered in two of the three secondary schools we visited. Both schools separated Catalan learners from the mainstream students until a certain level of proficiency had been acquired. Spanish, as the dominant language for social relations, appeared as the language that threatened Catalan, one of the cornerstones of the Catalan national identity.

A further development of $\mathrm{CN}$ that has proved highly productive is the small stories paradigm (Bamberg and Georgakopoulou 2008, Georgakopoulou, 2006, 2007, 2014). Georgakopoulou defines small stories "as a gamut of under-represented and 'a-typical' narrative activities, such as tellings of ongoing events, future or hypothetical events, shared (known) events, but also allusions to tellings, deferrals of tellings, and refusals to tell" (Georgakopoulou 2006: 130). She offers a model that draws on an eclectic theoretical framework, in order to analyse how identity is constructed in the complex interwoven discourses that tellers bring to the scene of communication when narrating personal daily life stories by drawing on a multidisciplinary framework that combines concepts and tools mainly from CA and sociolinguistics. Her contribution to the study of the construction of self in daily conversational narrative draws upon practice-based approaches that:

view language as performing specific actions in specific environments and as being part of social practices, shaping and being shaped by them (e.g. Hanks 1996). All narrative meaning making is seen as contextualized but also as having the potential to be lifted from its original context and to be re-contextualized, that is, to acquire new meanings in new contexts (see Bauman and Briggs 1990). Narrative thus ceases to be 
just a single event, and its historicity and circulation become part of the analysis. (Georgakopoulou, 2014: 4)

In this paper, I will use the umbrella term narrative repertoires to refer to small stories and $\mathrm{CN}$ indistinctly, in order to highlight their similar features, mainly those related to the contextual issues that influence the production of the narratives, as well as the worlds that the participants - in this case, parents of Latin American backgrounds who have migrated to Catalonia - depict in order to accomplish interactional objectives, according to their understanding of the situation. My analysis of the narratives will treat them as part of the communicative repertoires that actors have at their disposal in order to accomplish social activities (Rymes 2014), such as displaying particular identities, making relevant evaluations, aligning with moral orders and ideologies about language and about the situations they experience, but also, producing and reproducing certain social and institutional orders (De Fina 2008). I will show how small stories allow the Latin American parents to justify their decision not to learn Catalan, and reveal the responsibility that they give to their children for their own integration into Catalan society. I will link these narrative practices and repertoires with the wider story of the social processes in which they are produced, and at the same time help to (re)produce. Herein, language ideologies gathered and justified in small stories will be understood as indexes of the socialisation processes that these Latin American newcomers experience. I will combine structural and dimensional tools offered by Ochs and Capps (2001), some concepts from narratology, such as that of the focaliser (Genette 1983; Rimmon-Kennan 1983), and polyphony/ heteroglossia (Bakhtin, 1984), with ethnographic aspects that help to shed light on the conditions of production of such narratives and the ideologies and wider social phenomena that they evoke.

This paper aims to answer the following questions: 
- What language ideologies emerge in the narrative practices and narrative repertoires of Latin American parents within the Catalan education system?

- What narrative resources do parents, as tellers, use to convey language ideologies?

- How does an integrated analysis of the narrative repertoires produced as part of a linguistic ethnography carried out in a school help us to give an account of the language socialisation processes taking place within Latin American families living in Barcelona?

\section{Narratives and language ideologies circulating among Latin American parents:}

\section{Nora's case}

Nora's (big) story will allow us to illustrate our main analytical and methodological points regarding the use of $\mathrm{CN}$ among Latin American parents. These narrative repertoires are seen as sites for the construction and negotiation of particular positionings, as the expression of language ideologies that, according to parents, provide the reasons for particular linguistic behaviour, and also as sites for the circulation of such language ideologies. I will provide some ethnographic information taken from other parents' interviews and our experience in the field to demonstrate the circulation of such narratives amongst the Latin American group and reflect upon the social meaning of such narratives as part of the socialisation processes of this group of migrants in Catalonia.

Nora's interview was conducted in the office of one of the teachers at the Marc Aureli school, in May, 2011. She came to the school accepting the invitation sent out to parents of students in the Reception Class. A number of parents accepted the invitation, and most of them decided to come to the school rather than receiving us at home, as we would have preferred. Nora had been living in Barcelona for four years. She migrated as part of a cohort of workers in the hotel industry within the framework of an agreement between the Spanish 
and Colombian ministries of employment. She arrived first, followed six months later by her husband, and they managed to bring their children over two years later. At the time of the interview, Nora was a shift leader in a burger restaurant of one of the most important multinational chains, in central Barcelona. Despite feeling that the experience had been hard, she expressed happiness with her decision to migrate to Barcelona.

One of the members of our team, Larissa Tristán, of Latin American background (Costa Rica), conducted the interview. The fact that the interview was gathered at the school caused Nora to understand it as an institutional activity, as I will show in the analysis.

The analysis reveals that there is a complex constellation of language ideologies regarding Catalan, the language of the autonomous region's institutions, and the other languages (primarily Spanish and English) that coexist in the Catalan context. For the purposes of this paper, I will focus on the three central language ideologies that emerge in the narrative practices and repertoires of parents of Latin American backgrounds, which find echo among the students of Latin American backgrounds (see section 2): one nation - one language; (the logic of the linguistic market), anonymity and verbal hygiene. These ideologies are supported by some others beliefs that reinforce them, offering them an apparent 'ring of truth' and provide a rationale for the teller's linguistic behaviour. Our ethnographic approach will allow us to connect the ideologies that circulate in these narrative repertoires both with the parents' refusal to learn/speak Catalan and their interest in their children learning English, as well as with the children's linguistic ideologies.

\section{1 "Catalan is the language of here, we should respect it".}

A first common language ideology that emerges in Latin American parents' CNs is that of "one nation, one language". The materialisation of this language ideology in the discourses of students of Latin American backgrounds in Catalonia has been reported widely 
in our previous research (i.e. Newman, et al. 2013, Trenchs-Parera and Patiño-Santos 2013, Codó and Patiño-Santos 2014). Example 2 illustrates the communicative resources that Nora uses in order to construct her narrative and the way she evokes the "one nation, one language" ideology, as well as her discourse aligned with the nationalist official discourse produced by the local council:

\section{Example 2: Voicing the "Comencem a parlar"campaign}

Participants: Larissa/ researcher (in her early thirties) - Costa Rican origin/ Nora (in her mid40s) - Colombian origin.

141. LAR: y antes de viajar a Barcelona/ a Cataluña tú sabías que aquí se hablaba catalán además del castellano $\uparrow$

142. NOR: no/ (se ríe) // no/ fue una sorpresa cuando llegué y escuchaba hablar tan raro y yo pensaba / qué es eso?

143. LAR: te parecía raro $\uparrow$

144. NOR: sí/

145. LAR: por qué $\uparrow$

146. NOR: pues porque dice / qué función cumple ese idioma $\uparrow$ // sí/ porque en la vida lo escuchas/

147. LAR: y ahora/ a cuatro años de vivir aquí/ cuándo te haces esa pregunta tienes respuesta $\uparrow$

148. NOR: sí / claro porque es algo que es de aquí y que hay que respetarlo y que si me quiero quedar aquí /lo tengo que aprender/ $\uparrow / /$ tengo que esforzarme// aunque no lo aprenda del todo/ por lo menos entenderlo/ sabes $\uparrow$

149. LAR: entonces / eventualmente/ utilizas el catalán en el trabajo/

150. NOR: sí / a veces/

151. LAR: pero cuándo te piden algo en catalán respondes en catalán alguna vez $\uparrow$

152. NOR: no/ y me he inscrito en los cursos y todo pero por el horario del trabajo no he podido/

153. LAR: en cuáles cursos te has inscrito $\uparrow$

154. NOR: me inscribí en el básico de catalán pero apenas alcancé las primeras dos clases// fui a comprar el libro y ya está// y en el de inglés// igual// fui los primeros días pero ya no más// y claro/ ahí sí digo / porque nunca hice el inglés en la universidad $\downarrow$ / de hecho siempre fue la materia que he tenido pendiente// era el tabique mío siempre y aquí digo / Dios mío/ por qué no lo quise aprender $\downarrow$

141. LAR: and before coming to Barcelona/ to Catalonia did you know that here they spoke Catalan as well as Spanish $\uparrow$

142. NOR: no/ (she laughs) // no/ it was a surprise when I arrived and heard such weird talking and I thought / what's that?

143. LAR: so it seemed weird $\uparrow$ 
144. NOR: yes/

145. LAR: why $\uparrow$

146. NOR: well because you say /what use is this language $\uparrow / /$ yes/ because you simply never hear it/

147. LAR: and now/ after living here for four years/ when you ask yourself that question do you have an answer $\uparrow$

148. NOR: yes / of course because it's something from here and you have to respect it and if I want to stay here/ I've got to learn it // I've got to make the effort // even if I don't completely learn it/ at least I should understand it/ y'know $\uparrow$

149. LAR: so / in the end/ you use Catalan at work/

150. NOR: yes / sometimes/

151. LAR: but when they ask you something in Catalan do you sometimes answer in Catalan $\uparrow$

152. NOR: no/ and I've signed up for the courses and all that but because of my working hours I haven't been able to/

153. LAR: what courses have you signed up for $\uparrow$

154. NOR: I signed up for the basic Catalan course but I barely managed to do the first two classes// I went and bought the book but that was it// and in English/ the same story// I went to the first few days but then dropped out// and of course/ in that case I do say / why didn't I do English in the university $/ /$ in fact it was always the subject that I meant to get round to// it was always my mental block and here I say / oh my God/why didn't I want to learn it $\downarrow$

This example offers two relevant situations. The first one (141-148) shows certain narrative resources, including the construction of the setting (time and space), the use of a focaliser, evaluation and the transformation of the main character. These serve to convey

Nora's one nation-one language ideology.

In this first situation, Larissa constructs the setting and topic of the story: Nora's moment of arrival in Barcelona, and her previous knowledge concerning Catalan, one of the languages of her chosen destination. In turn 142, Nora's laughter indicates that the topic is a sensitive one, since Latin Americans speak Spanish and, as reported by eight of the parents interviewed, they expect that Spanish people will speak Spanish (Patiño-Santos, 2015). In order to mitigate her evaluation on the topic, Nora constructs herself as the ideological focaliser - the one who perceives and assesses the narrated events (Rimmond-Kennan 1983) - of an action in the past, when she arrived and "heard such weird talking and I thought / what's that?". Constructing herself as the focaliser of the event allows her to refer to Catalan 
as something weird, and to ask from her previous ignorance of the situation: "What's that?", or what is the function of "this language $\uparrow / /$ ", since Nora, in the present, would not describe the Catalan language thus, nor question its role in Catalan society, indicating (in her evaluation in 148) that she is now aware of the situation. Such an evaluation is reflected in narratives commonly found: all the interviewees report becoming aware of Catalan on arrival in Catalonia, and the importance of respecting and learning this language. Despite this, only two of the ten interviewees report having actually learnt it. Nora's alignment with the ideology "one nation-one language" is evident in her voicing of the official campaigns of the local Catalan government, based on "Catalan as the country's own language"4.

The second evoked situation (turns 149-154) presents the rationale for not speaking Catalan after four years living in Catalonia. In 151 Larissa asks about Catalan in the workplace. Nora does not use it, but immediately makes it relevant that she has enrolled in some Catalan classes. She shows that she has been active and has made some effort to learn the language, signalling the respect that she has mentioned in the previous situation (148). She states her reason straightforwardly in 152 ("but because of my working hours I haven't been able to/"). The most relevant part of this event is the small story introduced in 154 in order to give an explanation for failing to complete the language course. The narrative depicts her as the main character, who attended the two first classes of Catalan and did as much as was practically possible. However, without an obvious connection, she introduces a new narrative about her experience of trying to learn English. Even though both situations are described as unfinished projects, her frustration about not completing the English course deserves a lengthy moral evaluation that her dropping out from the Catalan course does not

\footnotetext{
${ }^{4} \mathrm{cf}$. the website of the local Catalan Government, -Generalitat de Catalunya- "Comencem a parlar campaign" Let's start speaking campaign, 2003
} 
receive: / "why didn't I do English in the university/ (...) / oh my God/ why didn't I want to learn it $\downarrow$

Although the example might be illustrating her lack of discipline when it comes to learning languages, English seems to be the unresolved matter in her life (rather than Catalan).

The analysis of this situation is in fact what caused us to interpret Nora's moral stance on the learning of Catalan at the beginning of the excerpt, as her way to judge the exchange to be an institutional activity. At the beginning of her memory, Nora shows awareness of a moral duty to learn Catalan, aligning with the discourse of the institution (she is being interviewed at her children's school). However instead of showing any qualms over not attending the Catalan classes, her evaluation in 154 shows her regret for not learning English, which might be interpreted as aligning herself with the most dominant language ideology in our data - "English is the most important language" - as we will see in the following section.

\section{2 "The most important language is English"}

The second shared language ideology that circulates in the narrative practices and repertoires of the Latin American parents and finds echo in the students' voices, is one widely explored in the research of language ideologies drawing on Bourdieu's theory of the linguistic market (1992), namely that languages hold distinct values. Following such a logic, according to all ten of our parent informants, Latin American indigenous varieties do not fulfil their definition of "languages", but count as "slang". At the other end of the spectrum, such criteria judge English to be "the most important language", since it is identified as a global language (Cameron 2012), as we will observe in example 5.

Examples 3 and 4 allow us to illustrate how the language ideology defined as anonymity by Woolard (1989), in which the authority of a dominant language is rooted in its 
"sounding like it is from "nowhere", its being "a common, unmarked standard public language" (Woolward 2008). This notion is central to their definition of what counts as language. Verbal hygiene (Cameron 1995) is also made relevant by the LA parents when comparing their Latin American varieties with the norm in the Spanish peninsular. Example 5 will introduce the circulating narrative of "English as the most important language".

In example 3, Nora defines what language is, by opposing language to slang, classing indigenous Latin American languages as "slang”, and explaining how her children's Spanish language uses have changed since they arrived in Barcelona. According to her definition, the term language applies solely to widely spoken varieties, such as English or Spanish:

Example 3: American Indigenous people speak slang

7. LAR: Ustedes son de Colombia, correcto $\uparrow /$ de cuál ciudad o región $\uparrow$

8. NOR: yo de Bogotá y mi esposo / de Pereira/

9. LAR: además del castellano / en su ciudad de origen hablan alguna otra lengua $\uparrow$

10. NOR: no / solo castellano/

11. LAR: y en Colombia se hablan algunas otras lenguas que usted conozca $\uparrow$

12. NOR: ah sí

13. LAR: cómo cuáles $\uparrow$

14. NOR: no las conozco / hay varias// las que tienen los indígenas/ son jergas, jergas internas/

15. LAR: pero entre ustedes / utilizan solamente el castellano

16. NOR: solo el castellano/

(...)

22. LAR: desde que llegaron acá, usted cree que los hábitos de lenguaje / es decir las palabras qué utilizan / cómo las utilizan

23. NOR: así / lo que es para ellos ha mejorado mucho en parte lo que es $\rightarrow$ aprendieron catalán pero igual han aprendido muchas palabrotas//

24. LAR: en qué en castellano o

25. NOR: en castellano dicen muchas más que allá

26. LAR: y por ejemplo las palabrotas de allá ya no las utilizan

27. NOR: no, o sea, hay palabrotas pero igual las que utilizan aquí son como más $\rightarrow$ y ellos ya las han aprendido entonces uno ya se acostumbra a escucharlos

7. LAR: you're from Colombia/ right? // from which city or region $\uparrow$

8. NOR: I'm from Bogotá and my husband's from Pereira.

9. LAR: apart from Spanish/ in your home city do they speak any other language? 
10. NOR: no/ just Spanish.

11. LAR: and in Colombia are there any other languages that you know of?

12. NOR: ah yes

13. LAR: like which ones $\uparrow$

14. NOR: I don't know them/ there are a number // the ones the indigenous people speak // they're slang/ slang just among themselves/

15. LAR: but between yourselves/ you just use Spanish $\uparrow$

16. NOR: just Spanish

(..)

22 LAR: since arriving here, do you think that their language habits / I mean, the words they use / how they use them

23 NOR: right / for them things have improved a lot partly what's $\rightarrow$ they learned a lot of Catalan but at the same time they have learned a lot of swear words//

24 LAR: in what in Spanish or

25 NOR: in Spanish they use far more than over there

26 LAR: and so they don't use the swear words from there any more

27 NOR: no, I mean, there are swear words but perhaps the ones they use here are stronger $\rightarrow$ and they've learnt them now so we're used to hearing them now

In this excerpt, the teller makes anonymity (Woolard 2008) and verbal hygiene (Cameron 1995) relevant as the legitimising ideologies for a language. In turn 8 Nora identifies herself as being from Bogotá, the capital city, a Spanish speaking place (10). The indigenous languages are constructed in opposition as "slang amongst the indigenous people", signalling that they are from far away, rural areas. Another parent represented in our data, of Argentinian origin, was at pains to point out that people in the urban areas do not have contact with these indigenous languages in her country.

The second part of the excerpt introduces verbal hygiene, which is one of the most widespread ideologies reported in Latin American parents' discourses - the claim that their children do not speak the Spanish of their Latin American origin anymore, but rather the Spanish from the Peninsula, full of "swear words". This belief was reported widely in my first research on Latin Americans in Madrid and Barcelona, where the conviction that, in Latin America, "we speak a better Spanish", was dominant in a group of twenty interviewees. As Marta, an informant from Madrid, noted, tautologies or repetitions are unacceptable in 
Colombian Spanish: "Here they treat Spanish very badly, saying for example Go up up (subir arriba) or Go down down" (bajar abajo) (Patiño-Santos 2005). So, we can observe how the ideology of verbal hygiene implies, in this case, a censorship of the Spanish spoken in Spain as being incorrect in comparison with the Spanish spoken in their Latin American countries of origin.

The idea that Latin American indigenous languages were not legitimate languages was a recurrent theme within our data. In example 4, Francisco, a parent of Ecuadorian background defines Quichua, one of the 'general indigenous languages' in South America, as a dialect:

Example 4: Quichua is a language within the Constitution

Participants: Larissa and Francisco of Ecuadorian origin.

20. LAR: cuál es su lugar preciso de procedencia $\uparrow$

21. FRA: Guayaquil / Ecuador

22. LAR: ahí hablan algún otro idioma además del castellano $\uparrow$

23. FRA: bueno / es un dialecto pero que ahora está asentado ante la constitución como idioma / es el Quéchua

20. LAR where do you come from exactly $\uparrow$

21. FRA Guayaquil/Ecuador

22. LAR: is there any other language there besides Spanish $\uparrow$

23. FRA: well / there is a dialect that has now been declared a language within the constitution / it's Quichua

In 23 Francisco makes his definition precise, by explaining Quichua as a dialect that has become a language within the Constitution. What is relevant is how the participant signals the fact that being legally recognised as a language does not necessarily entail its legitimacy as such. This raises the issue of the artificiality of minority languages, as observed by Frekko (2009) about the media's uses of Catalan, and identified in my previous research on Latin American young people's attitudes to Catalan (Trenchs Parera and Patiño-Santos 
2013), where the groups of Latin Americans from the schools visited declared themselves unable to find suitable registers to express their feelings.

The final section of example 2, from our interview with Nora, introduced English as the preferred second language to be learnt.

Example 5: English first

305. LAR: y pensando en el futuro / cuál lengua crees que le hablarán a sus hijos $\uparrow$

306. NOR: $\mathrm{hmm} \rightarrow$ con la mezcla que hay / no lo sé porque con la mezcla que hay

307. LAR: para ti (.) cuál es el idioma más importante que ellos tienen que aprender $\uparrow$

308. NOR: inglés y el que tenga la madre y el padre

305.LAR: and thinking about the future / in what language do you think your children will be spoken to $\uparrow$

306.NOR: um $\rightarrow$ with the mixture that's here / I don't know because with the mixture that's here

307.LAR: for you (.) what's the most important language that they ought to learn $\uparrow$

308.NOR: English and the language of their mother and father

"English first" was the most widespread language ideology expressed by Latin American parents, something which finds echo in students' discourses, as our research has shown (Corona and Unamuno 2008; Newman, et al. 2013). This ideology emerged in small stories about a hypothetical future, as we can see in the example. In Nora's answer, Larissa's question about the most important language to be learnt "in the future" mobilises the idea that English is first, and then the language of home ("the language of their mother and father"). This language ideology gives rise to a set of contradictions regarding the language practices observed in the workplaces/home and reported by parents in the interviews, as we will observe in 4.5. It also entails a hierarchisation of languages within an international linguistic market wherein English is identified as the global language (Cameron: 2012), Spanish might be the second in being an "international language", and Catalan is the least important for hardly being spoken outside Catalonia. 


\title{
5.3 A second language should be spoken correctly: Verbal hygiene
}

\author{
Example 6: The girl doesn't speak Catalan/ excuse her
}

103. LAR: y en el trabajo no te piden el manejo de otro idioma $\uparrow$

104. NOR: de todo//catalán/ inglés/ francés $\rightarrow$ tendría que saber todo//

105. LAR: y en cuál idioma te hablan los clientes $\uparrow / /$ por ejemplo/ si llega una persona catalana en cuál idioma te habla $\uparrow$

106. NOR: español eh catalán// si llega una persona catalana me habla en catalán pero en el momento en el que yo les contesto en español me cambian al español// hay quienes me hablan en español o hay quienes me siguen hablando en catalán pero igual yo les entiendo // les entiendo pero lo que me da miedo es contestar//

107. LAR: te da miedo contestarles $\uparrow$

108. NOR: sí/ sí porque luego lo digo mal y sabes $\uparrow / /$ y el catalán tiende a ser muy $\rightarrow$ si / no me lo vas a hablar bien/ no me lo maltrates

109. LAR: esa es tu percepción $\rightarrow$ // que si no lo hablas bien $\rightarrow$

110. NOR: no me lo maltrates // igual pensaría yo/ no $\uparrow$

111. LAR: ya te ha pasado que alguien/ cuando intentes hablar en catalán te diga algo negativo $\uparrow$

112. NOR: sí / sí

113. LAR: recuerdas alguna anécdota específica $\uparrow$

114. NOR: sí // un día un señor me dijo / un tallat / un café cortado / y yo le puse un café con leche // en ese tiempo llevábamos poquito tiempo y yo quedé $\downarrow$ // entonces el señor me dijo / no es un cortado // si no lo sabes/ por qué no me preguntas? / entonces yo le pedí una disculpa y mi jefe fue el que le dijo / la chica no sabe catalán/ discúlpala // y el señor le dijo // pues para qué cogen personas que no saben catalán $\downarrow$

115. LAR: él dijo eso $\uparrow$

116. NOR: sí // y mi jefe me dijo/ pasa/ pasa/ no le prestes atención // entonces en el trabajo sí que se nota mucho // por lo menos aquí la gente si tiende mucho $\mathrm{a} \rightarrow \mathrm{y}$ al uno ser jefe y haber empleados catalanes/ españoles también se nota montón

103. LAR: and at work do they not require you speak another language $\uparrow$

104. NOR: everything // Catalan/ English/ French $\rightarrow$ I'd have to know everything//

105. LAR: and what language do the customers talk to you in $\uparrow / /$ for example/ if a Catalan person comes in what language do they speak to you $\uparrow / /$

106. NOR: Spanish um Catalan // if a Catalan person comes they talk to me in Catalan but as soon as I answer them in Spanish they change to Spanish // there are some who speak to me in Spanish and some who carry on talking to me in Catalan but either way I understand them. I understand them but I'm just scared to answer//

107. LAR: you're scared to answer them $\uparrow$ 
108. NOR: yes/ yes because then I say something wrong and/ you know/ and a Catalan tends to be very $\rightarrow$ if you're not going to speak it properly/don't massacre it

109. LAR: is that your impression $\uparrow / /$ that if you don't speak it well $\rightarrow$

110. NOR: don't massacre it for me // maybe I'd think the same/ you know $\uparrow$

111. LAR: has it ever happened to you that/ when you try to speak Catalan they've said something negative $\uparrow$

112. NOR: yes/ yes

113. LAR: can you remember any specific anecdote $\uparrow$

114. NOR: yes // one day a man said to me / un tallat / a small coffee with just a touch of milk / and I gave him a normal white coffee // at that time we had only been here a short time and I was like $\rightarrow$ // so the man said to me / that's not a tallat // if you don't know what it is/ why don't you ask me? // so I said I was sorry and it was my boss who said to him / the girl doesn't speak Catalan/ excuse her // and the man said / so why do you take on people who can't speak Catalan $\downarrow$

115. LAR: he said that $\uparrow$

116. NOR: yes/ and my boss said to me // ignore it/ignore it/don't take any notice // so at work you do notice it a lot // at least here people definitely do tend to $\rightarrow$ and being an employer and having employed Catalans/ Spanish people as well you really notice it a lot

In turn 105, Larissa triggers a storytelling from Nora after asking her directly for an example to illustrate Nora's linguistic behaviour (// for example/ if a Catalan person comes in what language do they speak to you $\uparrow / /)$. In 106, Nora reports the most common linguistic behaviour documented in the Catalan sociolinguistic studies: the language choices of Catalan people can depend on their interlocutor. If a Catalan person is replied to in Spanish, they sometimes switch into Spanish (see for example: Boix 1993, Strubel i Trueta 1984; Woolard 1985; Pujolar 2001). Spanish-speaking employees are able to follow interactions either in Spanish or in Catalan (Marshall 2007, Trenchs-Parera and Tristán 2015). However, Nora’s resolution of this first small story "I understand them but I'm just scared to answer//", conveys a linguistic ideology, based on verbal hygiene (Cameron 1995) that will be elaborated in 108: Catalans do not accept Catalan being "badly spoken". Nora's perception of Catalans as owners of their language and guardians of its authenticity reproduces nationalist discourses. Such a discourse produces confusion amongst immigrants, who 
receive a double message, on the one hand the idea that Catalans welcome everyone who wants to speak their language, but at the same time, when immigrants try to speak the language, they are replied to in castellà (Spanish) (Pujolar 2007), and if they don't speak it 'correctly', they are criticised.

Nevertheless, Nora's definition of the situation is not illuminated by the story that she introduces in 114 in answer to Larissa's request for clarification. However, this rounded narrative is a suitable piece to illustrate another of the most common situations reported in our data: the idea that you can live and work in Catalonia without speaking Catalan. The narrative portrays a scene in Nora's workplace displaying different ideological voices (Bakthin, 1984). It introduces three characters representing conflicting language ideologies: Nora herself as the waitress, a Catalan speaking client and Nora's boss. Nora constructs herself in the narrative as somebody who does not speak Catalan, and evoking the ideology of "respect" explained in 4.1, apologises to the client because of her misunderstanding of the order (she brought him a normal white coffee, instead of a small coffee). The client becomes Nora's antagonist when reacting negatively to her mistake ("so the man said to me / that's not a tallat // if you don't know what it is/ why don't you ask me? //"). This opponent echoes an official nationalist voice, which sees the Catalan language as the basis of the Catalan nationalist project (Pujolar, 2007) (“why do you take on people who can't speak Catalan $\uparrow)$. A third ideological voice is introduced by the character of the boss, of Catalan origin, who defends Nora, adopting a laissez faire ideology and supporting her in private (ignore it/ ignore it/ don't take any notice //). Similar linguistic behaviours have reported in Marshall (2012) and in my previous work on Latino cafés and restaurants in La Sagrada Familia (Patiño-Santos, 2015). Businessmen, in this case managers, do not recognise familiarity with the Catalan language as a requirement for working and living in Catalonia, especially if their 
employees are members of the cheap labour force arriving in response to international agreements with Latin America.

\section{Discussion}

The ethnographic study of narrative practices and narrative repertoires amongst Latin American parents of a school located near the centre of Barcelona has allowed me to identify a constellation of language ideologies that circulate amongst this social group, and that I have organised under four labels: one nation - one language; (the logic of) the linguistic market; anonymity and verbal hygiene. These ideologies are mobilised and articulated in the storytelling practices produced by the social actors, as their justification for not speaking Catalan as well as for their explanations about their language choices. In some cases, these ideologies seem to be contradictory, but what we observe in parents' narratives is a hierarchisation of those sets of ideas in terms of the value that parents assign them. Thus, for example, Nora and the other parents expressed the need to respect Catalan as the language of Catalonia by aligning themselves with the one nation-one language ideology, but they all prioritised the English first ideology when thinking of their children's futures. Verbal hygiene becomes central for parents' ideas surrounding the Spanish spoken in Spain and their own varieties, when upholding their own ways of speaking (we speak a correct Spanish).

Even though we could not connect parents with their children's narratives, the fact that the ideologies revealed in those stories circulate amongst the Latin American community, becomes central to understand some of the beliefs about language uses in which both adults and children are being socialised. Finally, the polyphonic and heteroglossic (Bakhtin 1984) character of narratives told for, or coproduced with others, has allowed us to shed light on two complex issues: 
Firstly, we could identify some of the contradictions between parents' claims and their reported practices, as well as the possible consequences entailed by a lack of competence in Catalan. Thus, Nora's CN depicts her transformation at the moment of arrival in Catalonia, when she becomes aware of the existence of the Catalan language, and subsequently her efforts to learn it. She aligns herself morally with the official discourse in acknowledging the importance of Catalan in Catalonia, but her reality is that in her daily life she neither uses it at home nor in the public space where she works. Eight of the parents interviewed reported similar behaviour, and we were able to corroborate this when we interviewed them in their workplaces. In some cases, such as in Francisco's, they overtly state that they are not interested in learning Catalan. He and the other seven can understand the affection that Catalans hold for their language, but such an enterprise does not merit economic or time investment on their part. In this regard, whilst we observe language awareness in all of them, their language ideologies are not transformed. Catalan is acknowledged as a language in legal terms (in common with Quichua in Ecuador or Peru), but not as an effective means of communication. The circulating narrative that "you can survive in Catalonia without speaking Catalan" is true for those who do not want to participate in official jobs in local administration (in the education system, in health care services, local government, public libraries, and so on) - something I presented in a previous research on Colombians in La Sagrada Familia (2015). Along the same lines, English as "the most important language" was an ideology shared and mentioned by everyone represented in these data. English as the language of prestige and social and geographical mobility merits the investment that Catalan does not, but the contradiction is that none of these parents speak it. All of them, as in Nora's case, expect their children to learn it. The belief that "English is the language of the future" has become established in the parents' common mind-set as they seek the best for their 
children. In this regard, ensuring the learning English is treated as one of the duties of the good and caring parent.

Secondly, the polyphonic character of narratives allows us to connect the produced $\mathrm{CN}$ and the ideologies that they convey with the language ideologies reported and enacted by the students' of Latin American backgrounds in the Marc Aureli school and many others that I have visited in the course of the last ten years, when conducting ethnographic research with two different teams in Barcelona. In the case of the students, these language ideologies have been identified as one of the underlying factors in their refusal to speak Catalan at school or within their social environment. They do not see its function, utility or value in the sense that they do not find the expressive registers or the mobility that Spanish or English offer them. In some cases, Catalan is seen as a mere subject learnt at school, without material consequence for their lives. As my colleagues and I have widely presented and discussed, these students do not watch Catalan TV and tend to perceive speaking Catalan as an artificial practice. Catalan is the exclusive preserve of Catalans, or those who do well at school - including some Latin American students. Unfortunately, as we have also shown, such beliefs constrain their ability to compete effectively in the local labour market.

Methodologically, this study has allowed me to identify narrative genres (such as anecdotes, small stories, round stories, etc.) gathered in interviews and other interactional practices forming part of a linguistic ethnography, as apposite lenses for researchers to gain access to the participants' biographical data, including their daily life experiences as a group, the ideologies that underlie their practices, and the wider social order that provides the context for the production of the narratives themselves. This group of Latin Americans share not only experiences and challenges, but also circulating ideologies through their social encounters. The way these conversational narratives emerge between interactants (researcher and parents) of Latin American backgrounds in the course of the interview, and within the 
institutional context of the school, has also demonstrated the importance of such contextual conditions to the analysis of what is recounted and how it is expressed. The narrative resources used, in this case by Nora as our prototypical narrator, have shown, in accord with the wider field of narrative analysis, the effectiveness of constructing settings, depicting characters, drawing on small and round narratives in order to bring to the communicative scene particular or striking situations, adversaries they have encountered, helpful people and memories that might serve to support and illustrate their views. The study also allowed me to understand the ways in which narratives circulate in the community and the language ideologies that are shared by most of the members of this social group. Indeed, my experience, not simply as a researcher, but also as a Latin American who lived and worked in Catalonia for ten years been important in interpreting these ideologies and narratives.

In sum, $\mathrm{CN}$ has allowed me to uncover, through reported language practices (embodying language ideologies), situations and interactions, such as those of private family life, that were not directly accessible within the fieldwork.

\section{Acknowledgments}

I would like to acknowledge the support of my colleagues Mireia Trenchs and Michael Newman, and especially Larissa Tristán, for sharing their ideas with me. I would also like to thanks the Marc Aureli school community for supporting our research. the Catalan and Spanish language teachers, the students who were important mediators between the researchers and their parents, and the parents for agreeing to be interviewed.

\section{References}


Bakhtin, Mikhail M. 1984. Problems of Dostoevsky's poetics. (ed.) and trans. Caryl Emerson. Minneapolis: University of Minnesota Press.

Bamberg, Michael and Alexandra Georgakopoulou. 2008. Small stories as a new perspective in narrative and identity analysis. Text and Talk 28. 377-396.

Bamberg, Michael, Anna De Fina, and Deborah Schiffrin (eds.). 2007. Selves and identities in narratives and discourse. Amsterdam: John Benjamins.

Boix, Emili. 1993. Triar no és trair. Identitat i llengua en els joves de Barcelona [Choosing is not betraying. Identity and language among youths in Barcelona]. Barcelona: Edicions 62.

Bourdieu, Pierre. 1992. Language and symbolic power. Cambridge: Polity Press.

Cameron, Deborah. 1995. Verbal hygiene (The Politics of Language). New York: Routledge

Cameron, Deborah. 2012. The commodification of language: English as a global commodity. In Terttu Nevalainen and Elizabeth Closs Traugott (eds.) The Oxford handbook of the history of English, 352-364. Oxford: Oxford University Press.

Codó, Eva and Adriana Patiño-Santos. 2014. Beyond language: class, social categorisation and academic achievement in a Catalan high school. Linguistics and Education 25. $51-63$.

Corona, Víctor and Virginia Unamuno. 2008. Reflexión, conciencia e ideología lingüísticas en el discurso de jóvenes latinoamericanos [Reflexivity, language awareness and language ideologies in the discourse of young Latin Americans]. Textos de Didáctica de la Lengua y la Literatura 49. 48-56.

Corona, Víctor, Lucy Nussbaum and Virginia Unamuno. 2013. The emergence of new linguistic repertoires among Barcelona's youth of Latin American origin. In Kathryn A. Woolard and Susan E. Frekko (eds,), Special issue: Catalan in the Twenty-First 
Century. International Journal of Bilingual Education and Bilingualism 16(2). 182194.

De Fina, Anna. 2003. Identity in narrative. A study of immigrant discourse. Amsterdam: John Benjamins.

De Fina, Anna. (2008). Who tells which story and why? Micro and macro contexts in narrative. Text \&Talk-An Interdisciplinary Journal of Language, Discourse Communication Studies 28(3). 421-442

De Fina, Anna and Alexandra Georgakopoulou (eds.). 2008. Narrative analysis in the shift from text to practices. Special Issue Text \& Talk 28 (3).

De Fina, Anna and Alexandra Georgakopoulou. 2012. Analyzing narrative. Discourse and sociolinguistic perspectives. Cambridge: Cambridge University Press.

De Fina, Alexandra, Deborah Schiffrin and Michael Bamberg. (eds.). 2006. Discourse and identity. Cambridge: Cambridge University Press.

Frekko, Susan. 2009. « Normal » in Catalonia : Standard language, enregisterment and the imagination of a national public. Language in Society 38. 71-93.

Genette, Gérard. 1983. Narrative discourse revisited. Ithaca: Cornell UP.

Georgakopoulou, Alexandra. 2007. Small stories, interaction and identities. Amsterdam/ Philadelphia: John Benjamins.

Georgakopoulou, Alexandra. 2008. 'On MSN with buff boys' self- and other-identity claims in the context of small stories. Journal of Sociolinguistics 12. 597-626.

Georgakopoulou, Alexandra. 2006. The other side of the story: towards a narrative analysis of narratives-in-interaction. Discourse Studies 8. 265-287.

Georgakopoulou Alexandra. 2014. Between narrative analysis and narrative inquiry: The long story of small stories research. Working Papers in Urban Language and Literacies, Paper 131. (accessed 24 April 2015). 
Gibson Margaret A. and Silvia Carrasco. 2009. The education of immigrant youth: Some lessons from the U.S. and Spain. Theory into Practice 48. 249-257.

Huguet, Ángel and Judit Janés, J. 2008. Mother tongue as a determining variable in language attitudes. The case of immigrant Latin American students in Spain. Language and Intercultural Communication 8(4). 246-260.

King, Kendall and Anna De Fina. 2010. Language policy and the discourse analysis of individual experience: Latina women's perspectives on language policy in the U. S. Applied Linguistics 31(5). 641-670.

Lanza, Elizabeth and Bente Ailin Svendsen. 2007. Tell me who your friends are and I might be able to tell you what language(s) you speak: Social network analysis, multilingualism, and identity. International Journal of Bilingualism 11 (3). 275-300.

Labov, William. 1972 The Transformation of Experience in Narrative Syntax. In William Labov (ed.) Language in the Inner City: Studies in the Black English Vernacular, 354-596. Philadelphia: University of Pennsylvania Press.

Marshall, Steve. 2007. New Latino diaspora and new zones of language contact: A social constructionist analysis of Spanish speaking Latin Americans in Catalonia. In Johnatan Holmquist, Augusto Lorenzino and Lotfi Sayahi (eds.), Selected Proceedings of the Third Workshop on Spanish Sociolinguistic, 150-161. Somerville, MA: Cascadilla Proceedings Project.

Marshall, Steve. 2012. The story of the tallat: Latin American bar workers, Catalan-speaking customers, and coffee. Spanish in Context (9)3. 400-419.

Newman, Michael. 2011. Different ways to hate a language in Catalonia: Interpreting low solidarity scores in language attitude studies. In Jim Michnowicz and Robin Dodsworth (eds.), Selected proceedings of the 5th workshop on Spanish 
sociolinguistics, 409. Somerville,MA: Cascadilla Proceedings Project. http://www.lingref.com Document \#2504 (access September 2014).

Newman, Michael, Adriana Patiño-Santos and Mireia Trenchs-Parera. 2013. Linguistic integration of Latin American immigrants in Catalonia and their responses to the implementation of educational language policies. In special issue: Catalan in the twenty-first century. International Journal of Bilingual Education and Bilingualism 16, (2). 195-209.

Ochs, Elinor and Lisa Capps. 2001. Living narrative: Creating lives in everyday storytelling. Cambridge, MA: Harvard University Press.

Oller, Judit and Ignasi Vila. 2010. Effects of sociolinguistic environment and the length of residence on the linguistic performance in Catalan and Spanish of sixth grade immigrant pupils in Catalonia. Sociolinguistic Studies 4(1). 63-84.

Patiño-Santos, Adriana. 2005. Narrativas de la inmigración colombiana en Madrid y Barcelona [Narratives of Colombian immigration in Madrid and Barcelona]. MA dissertation. UAB.

Patiño-Santos, Adriana. 2015. On being a Latin American in La Sagrada Familia: the negotiation of identities and the construction of authenticity. In Rosina MárquezReiter and Luisa Martín Rojo (eds.) A sociolinguistics of diaspora: Latino practices, identities and ideologies, 102-121. Abingdon, GB Series: Routledge.

Pujolar, Joan. 2001. Gender, heteroglossia and power: a sociolinguistic study of youth culture. Berlin: Mouton de Gruyter.

Pujolar Joan. 2007. The future of Catalan: Language endangerment and nationalist discourses in Catalonia. In Alexander Duchêne and Monica Heller (eds.) Discourses of endangerment, 121-148. London: Continuum. 
Razfar, Aria. 2012. Narrating beliefs: A language ideologies approach to teacher beliefs. Anthropology of Education Quarterly 43(1). 61-81.

Relaño Pastor, Ana María. 2014. Shame and pride in narrative: Mexican women's language experiences at the U.S.-Mexico border. New York: Palgrave.

Rimmon-Kennan, Shlomith. 1983. Narrative fiction. Contemporary Poetics. London: Methuen and Co. Ltd.

Rymes, Betsy. 2014. Communicating beyond language: Everyday encounters with diversity. New York: Routledge.

Rumsey, Alan. 1990. Wording, meaning, and linguistic ideology. American Anthropologist $92.346-361$.

Strubel i Trueta, Miquel. 1984. Language and identity in Catalonia. International Journal of Sociology of Language 47. 91-104.

Trenchs-Parera, Mireia and Michael Newman. 2009. Diversity of language ideologies in Spanish-speaking youth of different origins in Catalonia. Journal of Multilingual and Multicultural Development 30(6). 509-524.

Trenchs-Parera, Mireia and Adriana Patiño-Santos. 2013. Language attitudes of LatinAmerican newcomers in three secondary school reception classes in Catalonia. In Arnau, Joaquim (ed.) Reviving Catalan at School: Challenges and Instructional Approaches, 49-71. Multilingual Matters - Institut d'Estudis Catalans.

Trenchs-Parera and Larissa Tristán. 2015. Interaccions al barri: un estudi de les pràctiques lingüístiques dels joves immigrants i les seves famílies a Catalunya [Interactions in the neighborhood: a study of the linguistic practices of young migrants and their families in Catalonia] Col·lecció Ciutadania i Immigració - núm. 10. Recerca $i$ Immigració VI. Barcelona: Generalitat de Catalunya. 143-165. 
http://treballiaferssocials.gencat.cat/web/.content/01departament/08publicacions/colec cions/ciutadania_i_immigracio/11recercaimmgracio6/recerca_immigracio_sis.pdf (accessed December 10, 2015)

Unamuno, Virginia and Luci Nussbaum. 2006. De la casa al aula: ámbitos y prácticas de transmisión y aprendizaje de lenguas. [From home to classroom: environments and practices in the transmission and learning of languages] Textos de Didáctica de la Lengua y de la Literatura 42. 43-51.

Woolard, Kathryn A. 1985. The dilemma of language rights. In Wolfson Nessa and Joan Manes (eds.) Language of inequality. Berlin: Walter de Gruyter: 91-110.

Woolard, Kathryn A. 1989. Double talk: Bilingualism and the politics of ethnicity in Catalonia. Stanford: Stanford University Press.

Woolard, Kathryn A. 2008. Language and identity choice in Catalonia: The interplay of contrasting ideologies of linguistic authority. Süselbeck, Kirsten, Ulrike Mühlschlegel and Peter Masson (eds.) Lengua, nación e identidad. La regulación del plurilingüismo en España y América Latina, 303-323. Frankfurt am Main: Vervuert/Madrid: Iberoamericana.

Wortham, Stanton. 2001. Narratives in action. A strategy for research and analysis. New York: New Teachers College.

\section{Appendix 1}

\section{Symbols used in transcripts}

PART: participant

A (Capital letters) loud talking aa lengthening of vowel or consonant sound / short pause ( 0.5 seconds) // long pause $(0.5-1.5$ seconds $)$

(( )) non-understandable fragment $\downarrow$ descending intonation

$\uparrow$ rising intonation

$\rightarrow$ continuing intonation

[ ] turn overlapping with similarly marked turn

Cat: fragment in Catalan 
